\title{
The anthochron as a building block of flower development
}

\author{
Nereu Augusto Streck ${ }^{(1)}$ and Natalia Teixeira Schwab ${ }^{(1)}$ \\ (1)Universidade Federal de Santa Maria, Avenida Roraima, o 1.000, Cidade Universitária, Camobi, CEP 97105-900 Santa Maria, RS, Brazil. \\ E-mail: nstreck2@yahoo.com.br, natalia_schwab@hotmail.com
}

\begin{abstract}
Plant vegetative development has been widely described using the phyllochron concept, but little effort has been made to describe flower development during the reproductive phase. The objective of this work was to present the anthochron, through a review of the literature, as a building block of flower development, mainly during the flower opening phase. The anthochron is the time interval needed for two subsequent flowers to achieve the same developmental stage, with units of time in days or in ${ }^{\circ} \mathrm{C}$ day per flower. The concept of anthochron fulfills part of the lack of studies on flower development, since it is considered a building block of the flower opening process. The anthochron can be measured from field experiments or estimated by a simple linear regression analysis. So far, the anthochron has only been quantified in Gladiolus x grandiflorus Hort. Therefore, factors affecting the anthochron still need to be determined in order to pinpoint their effect on the flower opening rate.
\end{abstract}

Index terms: anthesis, development unit, inflorescence, reproductive development.

\section{O antocrono como unidade básica do desenvolvimento floral}

Resumo - O desenvolvimento vegetativo de plantas tem sido amplamente descrito com a utilização do conceito de filocrono, porém pouco esforço tem sido feito para descrever o desenvolvimento da flor durante sua fase reprodutiva. O objetivo deste trabalho foi apresentar, por meio de uma revisão da literatura, o antocrono como unidade básica do desenvolvimento floral, especialmente durante a fase de abertura de flores. $\mathrm{O}$ antocrono é o intervalo de tempo necessário para duas flores subsequentes atingirem o mesmo estágio de desenvolvimento, com unidades de tempo em dias ou $\mathrm{em}^{\circ} \mathrm{C}$ dia por flor. O conceito do antocrono preenche parte da falta de estudos sobre o desenvolvimento floral, uma vez que é a unidade básica do processo de abertura floral. $\mathrm{O}$ antocrono pode ser medido a partir de experimentos em campo ou estimado por análise de regressão linear simples. Até o momento, o antocrono foi quantificado apenas em Gladiolus x grandiflorus Hort. Portanto, os fatores que afetam o antocrono ainda precisam ser determinados para identificar o seu efeito na taxa de abertura floral.

Termos para indexação: antese, unidade de desenvolvimento, inflorescência, desenvolvimento reprodutivo.

\section{Introduction}

Studies on plant development and growth analysis have been in the agenda of biologists, plant scientists, and environmentalists, among others. Although development and growth are related processes that often take place simultaneously during most of the life span of plants, they are distinct from each other (Wilhelm \& McMaster, 1995). Growth is usually defined as an irreversible increase in any physical dimension, including length, area, volume, and mass, being a concept that ultimately implies a plant increasing in size (Reichardt \& Timm, 2012). Development, in turn, is a much more complex term, since it represents a set of processes from organ initiation and differentiation to plant senescence (Wilhelm \& McMaster, 1995). Therefore, development is used to describe how a plant passes through several physiological changes throughout its life cycle, at the end of which seeds are formed and matured in order to perpetuate the species (Reichardt \& Timm, 2012). These definitions are applicable to a single plant as well as to a canopy.

The developmental cycle of a plant or a crop can be divided into two major phases: vegetative and reproductive. During the vegetative phase, structural organs, such as leaves, stem, and roots, are differentiated and grow. Plant development during this phase has been widely described using the concept of phyllochron (Streck et al., 2007; Rosa et al., 2009; Costa et al., 2014; Martins et al., 2014), defined as the time interval between the appearance of two successive leaves on the stem (Wilhelm \& McMaster, 1995; Skinner \& Nelson, 1992). From this perspective, the vegetative phase can be understood 
as the result of the accumulation of phyllochron units, which are considered the building blocks of vegetative development. The phyllochron concept has been widely applied to annual and perennial crops (Streck et al., 2007; Rosa et al., 2009; Streck et al., 2012; Costa et al., 2014; Martins et al., 2014; Rodrigues et al., 2014; Davidson et al., 2015), and genetic and environmental factors that affect the phyllochron, as temperature, soil moisture, and photoperiod, have also been identified (Kirby, 1995). However, concerning the reproductive phase, less effort has been dedicated to describe flower development, especially with regard to the flower opening rate on inflorescences.

Many processes related to flower development have been widely studied, including the transition from the vegetative to the reproductive phase, the effects of nutrients and hormones (mainly gibberellins) on flowering, circadian rhythms, and photoperiodism (Reid \& Evans, 1986; Taiz \& Zeiger, 2009). According to Doorn \& Meeteren (2003), flower opening in many species is accompanied by a high rate of cell expansion, movements (for instance, phototropism), and a complex regulation by external (environmental) and internal (carbohydrate supply, water potential, and hormones) factors. However, important questions still remain: How to study or describe the flower opening rate? What is the importance of the flower opening rate? Which factors drive flower opening on an inflorescence?

Recently, Schwab et al. (2014) proposed the term "anthochron" (formed from the Greek words anthos = flower and chronos $=$ time) to define the time interval between the opening of successive flowers on an inflorescence. This concept is one possible answer to the first question raised above, and can be the starting point for studies on the flowering opening rate, leading to a better understanding of the development during the reproductive phase of plants.

The objective of this work was to present the anthochron, through a review of the literature, as a building block of flower development, mainly during the flower opening phase.

\section{The importance of flower development}

The economic parts of agricultural crops vary greatly, comprising: roots (for example, cassava, carrot, and sweet potato), stem (sugar cane and potato), leaves (forage crops and lettuce), fruits (apple, grape, peach, watermelon, and tomato), seeds (grain crops, such as rice, soybean, corn, and wheat, among others), and flowers (rose, gladiolus, and lily). Of these groups, fruit, seed, and flower crops directly depend on flower development.

Regarding flower crops, their inflorescences or single flowers are the main economic part. For cut flowers, postharvest development plays a decisive role in defining the marketable product both in terms of quality to attract consumers as well of their vase life or postharvest life. The postharvest life of many cut flowers involves a period during which the flower opens from the bud or near-bud stage (Reid \& Evans, 1986). Therefore, a comprehensive understanding of the flower opening rate can be useful for planning harvest and product delivery management practices that accelerate or delay the process. According to Reid \& Evans (1986), techniques for handling cut flowers may include early bud harvest and storage, and would, therefore, require better understanding of the mechanisms of bud opening.

Besides its importance for flower crops, flower development is also crucial for fruit and seed crops, since fruits and seeds develop from flowers. Therefore, by determining the time interval of flower opening in a given crop and the factors that drive the rate, it may be possible, for instance, to make some inferences on the pollination processes, which are essential for seed and fruit setting in cross-pollination species. The time of flower opening marks the onset of a period in which pollinators will be attracted, leading to pollen removal in male and bisexual flowers, as well as to pollination, fertilization, and fruit and seed set in female and bisexual flowers (Doorn \& Meeteren, 2003). Therefore, ultimately, factors that affect the flower development rate may potentially affect fruit and seed set.

\section{Describing the flower opening rate}

\section{The morphological basis for defining the anthochron}

Vegetative development can be represented by the cumulative number of leaves (Counce et al., 2000), which are responsible for intercepting solar radiation for photosynthesis. This same idea can be used to represent flower development, i.e., the accumulation of a number of flowers on an inflorescence may define the progress of flower crop development. Just 
as the number of leaves is based on dichotomous morphological criteria, as, for example, whether a leaf is visible or not (Counce et al., 2000; Streck et al., 2003), the number of flowers can also be determined by a morphological criterion that is either present or absent. Schwab et al. (2014), while studying gladiolus, used the presence of anthers visible to the observer as a dichotomous criterion to define if a floret is open or not. However, other criteria may be suitable, considering that angiosperms show morphological differences regarding reproductive structures and flower-opening mechanisms. In Oenothera spp., for instance, a zipper-like mechanism keeps sepals connected and the petals are suddenly released as they grow (Door \& Meeteren, 2003). As new flowers meet the morphological criteria for opening, flower development progresses towards the end of flowering, until the final number of flowers is achieved, just like the final leaf number marks the end of the leaf appearance phase (Counce et al., 2000; Schwab et al., 2015). Considering this, the anthochron can be defined as the time interval needed for two subsequent flowers to achieve the same developmental stage, based on morphological criteria for opening.

The concept of anthochron is useful in many cut flower species, such as gladiolus and freesia, in which inflorescences are harvested commercially in the bud stage, before flowers are fully developed (Reid \& Evans, 1986). The anthochron is also a useful concept in species that have either indeterminate inflorescences, which include the raceme, corymb, spike, panicle, spadix, umbels, catkin or ament, and head or capitulum; or determinate inflorescences, such as simple cyme, compound cyme, glomerule, and syconium (Vidal \& Vidal, 2007). On inflorescences, flowers usually do not open at the same time, and the anthesis phase lasts several days or weeks. In this case, the opening time of successive flowers in the same inflorescence allows determining the flowering period, which is important both for defining the vase life as well as the period when flowers are suitable for pollination in species that produce seeds.

\section{Measuring and estimating the anthochron}

The anthochron can be measured directly from field observations or can be estimated by a simple regression analysis approach. Field observations include visiting plants on a daily basis and taking notes on the day when individual flowers on the inflorescence reach a developmental stage based on previously defined morphological criteria. For instance, if the morphological criterion for flowering is "visible anthers", then the day when the anthers are first visible to the observer is the day in which the flower is open. Using the same criterion, the day when the next flower of the inflorescence is open marks the time period for two successive flowers, i.e., the anthochron. If other practical criteria are used, such as the percentage of flower appearance or the percentage of floral buds opening, the anthochron can also be estimated by subtracting the percentage in day " $n$ " and the percentage in day " $n-1$ ". An example of when anthesis is used as the morphological criterion to indicate open flowers and of the representation of the anthochron in Gladiolus $\mathrm{x}$ grandiflorus Hort. is given in Figure 1.

It should be noted, however, that daily field observations are very time consuming. To overcome this constraint, field observations on the number of open flowers can be made once or twice a week, and, with these data, the anthochron can be estimated using a simple linear regression of the accumulated number of flowers against time (Figure 2). The slope of the linear regression represents the flower opening rate, and the anthochron can be estimated as the inverse of the slope of the regression, i.e., anthochron $=1 / \mathrm{a}$, with unit of time per flower (Schwab et al., 2014). This approach is similar to the one used to estimate the phyllochron (Rosa et al., 2009; Costa et al., 2014; Martins et al., 2014).

An important underlying assumption for estimating the anthochron from simple linear regression (Figure 2) is the strong dependence of flower development on time; in this case, the coefficient of determination $\left(\mathrm{R}^{2}\right)$ of the linear regression should be the closest to 1 as possible (above 0.95). Schwab et al. (2014), for instance, in gladiolus, estimated the anthochron as varying from 0.99 to 1.36 days per floret, with a $\mathrm{R}^{2}$ ranging from 0.96 to 0.97 . It is crucial to take into account the major factors that control individual flower development when defining the independent variable in Figure 2 $(\mathrm{X}$-axis $=$ time $)$. For example, if temperature affects the flower opening rate, then thermal time $\left({ }^{\circ} \mathrm{C}\right.$ day) should be preferred to calendar time (days or weeks) as the X-variable (Figure 2).

Pesq. agropec. bras., Brasília, v.51, n.8, p.899-904, ago. 2016 DOI: 10.1590/S0100-204X2016000800001 


\section{Applications of the anthochron}

Reproductive development in plants is much more complex than vegetative development. It starts when primordia differentiate into reproductive structures at the apex and lasts until the senesce of the reproductive structures. During this period, flower development is an important part of the reproductive development for several reasons. During flowering, pollination defines the onset of fruit and seed growth and development (Doorn \& Meeteren, 2003). In addition, the rate that flowers open defines the rate that fruit set takes place.

The anthochron as a building block of the flower opening process can be used to study species with inflorescences botanically classified as indeterminate, among which are: the raceme (Figure 3 A) in Vitis vinifera L., Crotalaria zanzibarica Benth., and Consolida ajacis Nieuwl.; the spike (Figure $3 \mathrm{~B}$ ) in Gladiolus x grandiflorus Hort., Liatris spicata (L.) Willd., and Curcuma longa L.; and the panicle (Figure $3 \mathrm{C}$ ) in Oryza sativa L. and Gypsophila paniculata L. In panicle-type inflorescences, where flowers are located on secondary branching from a main rachis (Figure $3 \mathrm{C}$ ), a regression analysis can be performed for each branch and some overlapping of flower opening among branches on the inflorescence is expected.

In cut flower crops, such as Gladiolus x grandiflorus Hort., Antirrhinum majus L., Gypsophila paniculata L., C. ajacis, Solidago canadensis L., L. spicata, and C. longa, the anthochron can be used to estimate the durability or shelf life of floral stems. The anthochron may also help in defining post-harvest management practices, such as storage temperature and light (Reid \& Evans, 1986). Another use of the anthochron is in crop simulation models to simulate the dynamics of flower development during the reproductive phase. However, so far, the anthochron has only been quantified in gladiolus (Schwab et al., 2014), indicating that it needs to be studied in many other crops.

Errors when estimating the anthochron from linear regression analysis (Figure 2) can lead to an underestimation or to an overestimation of the flower opening rate. Such errors can be related to environmental and internal plant factors that affect flower opening (Doorn \& Meeteren, 2003) and should
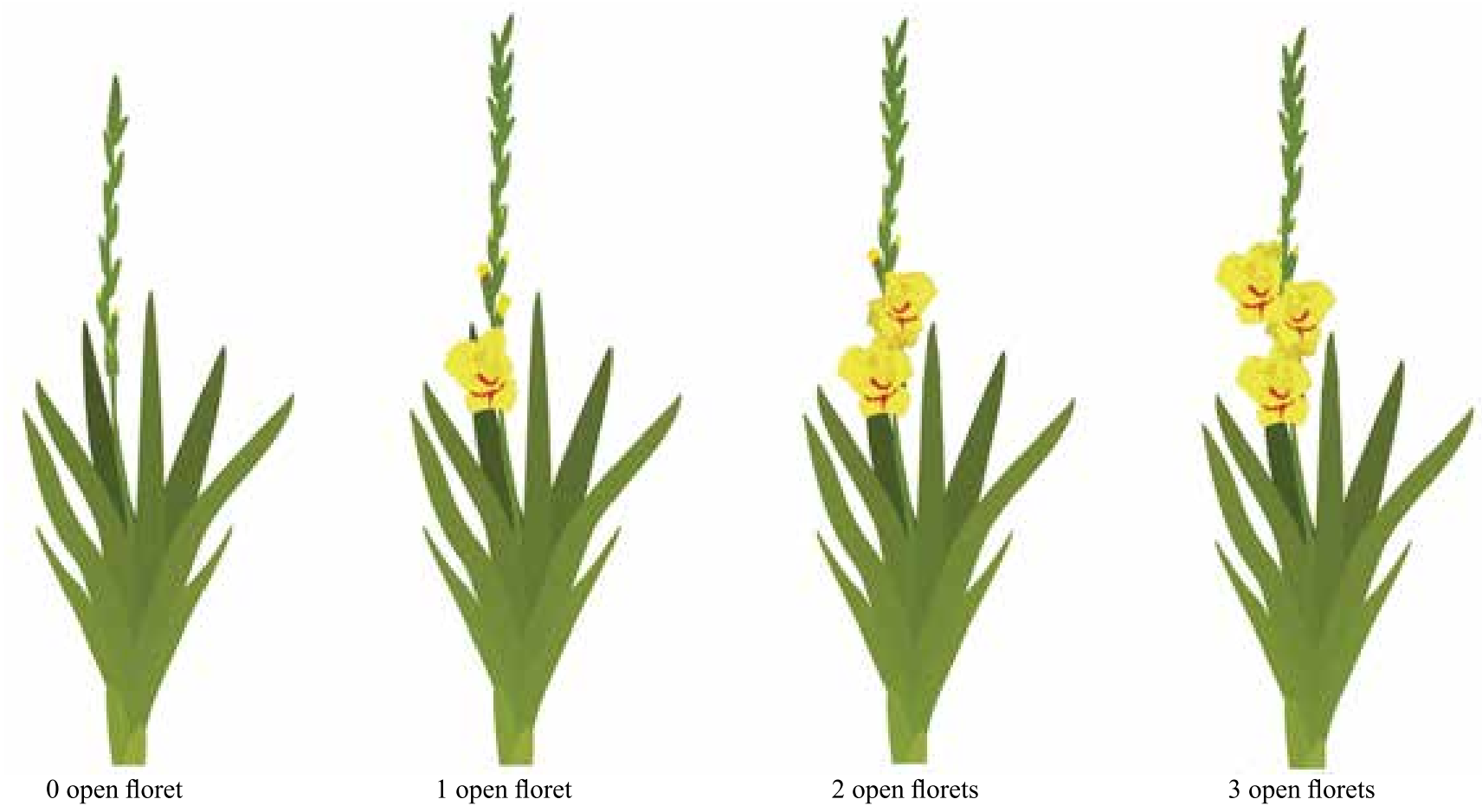

Figure 1. Open florets in Gladiolus x grandiflorus Hort., according to the defined morphological criterion of anthers visible to the observer. The time interval between the opening of two successive florets is the anthochron. 


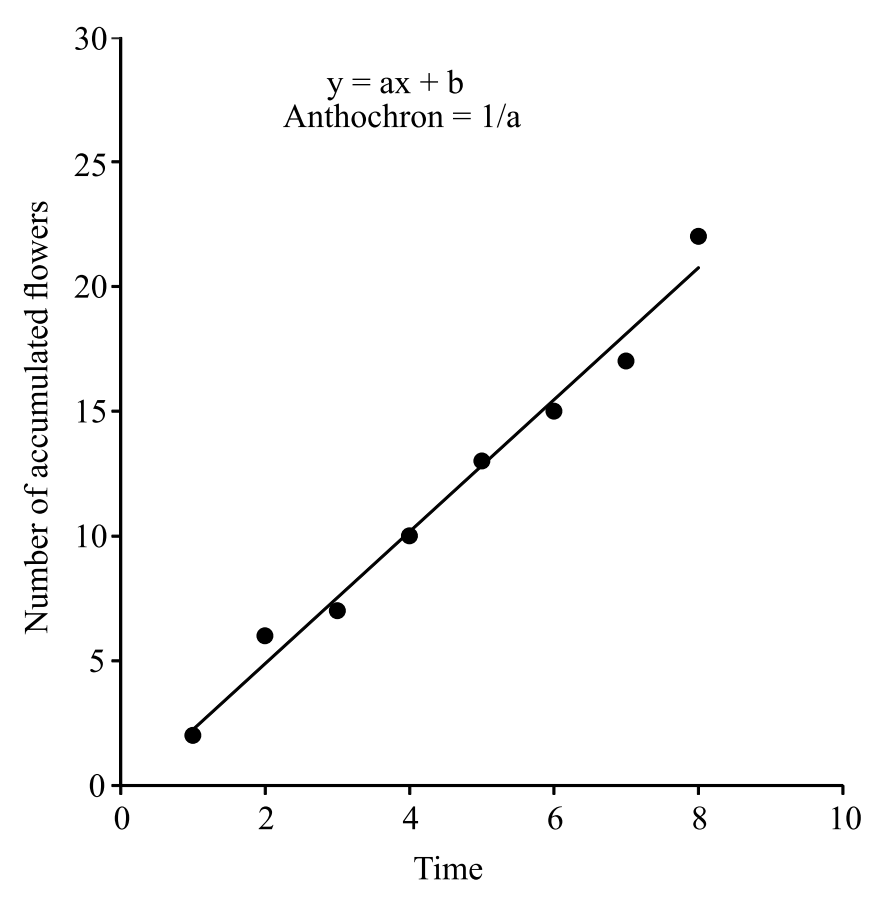

Figure 2. Simple linear regression of the number of accumulated flowers against time. The inverse of slope a of the linear regression is an estimate of the anthochron. be included in the X-axis of the regression. Some of these potential factors are mentioned as follows.

\section{Factors affecting the anthochron}

During the reproductive phase, plants of several species allocate a huge amount of photosynthetic energy for flowering. Energy comes basically from the mobilization of storage carbohydrates (Doorn \& Meeteren, 2003) and, therefore, any factor that affects carbohydrate production and translocation may potentially affect the anthochron. Among these factors are: temperature, quality and quantity of light, duration of both light and darkness, and water supplied (Reid \& Evans, 1986; Doorn \& Meeteren, 2003). Minor factors that are hypothesized to affect the anthochron include plant density, plant disease and insects, and interspecific competition with weeds. Given that the term anthochron has only been recently proposed (Schwab et al., 2014), the role of each of these factors in affecting it still has to be quantified for different species, which constitutes the rationale for many studies to come.

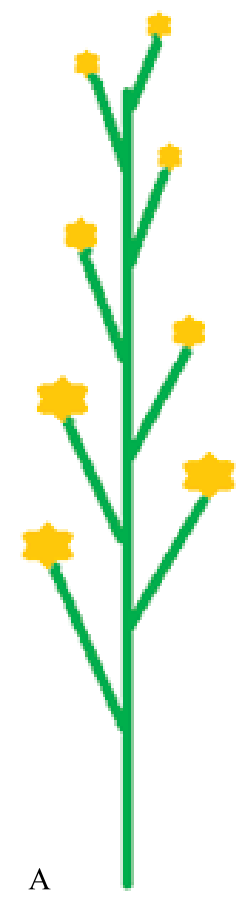

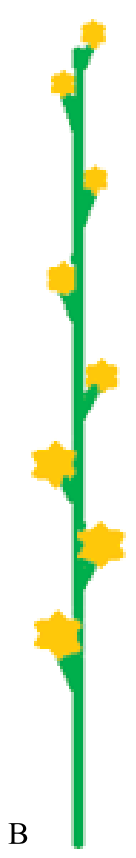

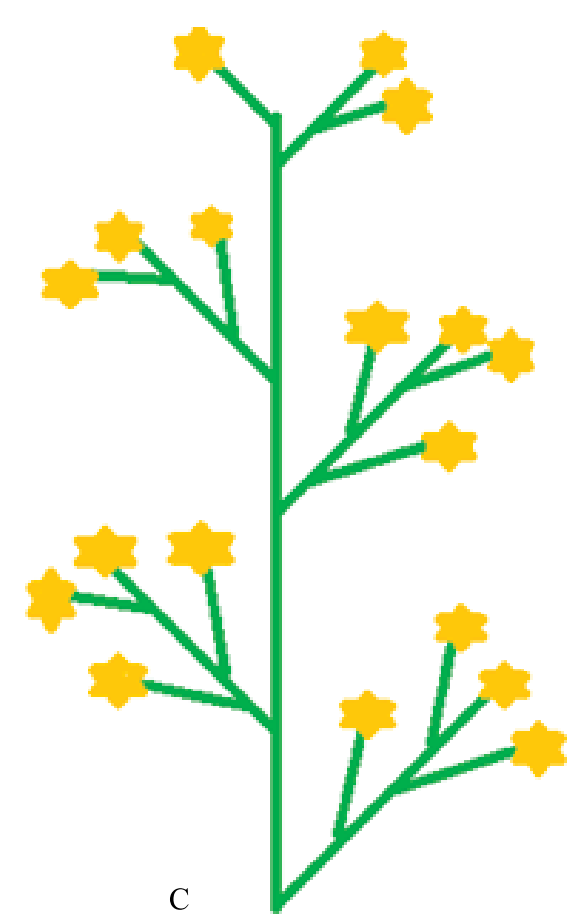

Figure 3. Inflorescence types to which the anthochron concept is applicable: A, raceme; B, spike; and, C, panicle. 


\section{Concluding Remarks}

Little effort has been made to describe flower development compared with vegetative development in agricultural crops. The concept of anthochron as a building block of flower opening fulfills part of this gap. The anthochron can be measured from field experiments or estimated by a simple regression analysis. So far, the anthochron has only been quantified in Gladiolus x grandiflorus Hort. Therefore, factors affecting the anthochron still need to be determined in order to pinpoint if they play a major role in affecting the flower opening rate and, consequently, the anthochron.

\section{Acknowledgement}

To Conselho Nacional de Desenvolvimento Científico e Tecnológico (CNPq), for financial support.

\section{References}

COSTA, R.C. da; CALVETE, E.O.; MENDONÇA, H.F.C.; CECATTO, A.P. Phenology, phyllochron, and gas exchanges in frigo and fresh strawberry (Fragaria $\times$ ananassa Duch.) plants of cv. Albion. Australian Journal of Crop Science, v.8, p.901-908, 2014.

COUNCE, P.A.; KEISLING, T.C.; MITCHELL, A.J. A uniform, objective, and adaptive system for expressing rice development. Crop Science, v.40, p.436-443, 2000. DOI: 10.2135/ cropsci2000.402436x.

DAVIDSON, A.; SILVA, D. da; QUINTANA, B.; DEJONG, T.M. The phyllochron of Prunus persica shoots is relatively constant under controlled growth conditions but seasonally increases in the field in ways unrelated to patterns of temperature or radiation. Scientia Horticulturae, v.184, p.106-113, 2015. DOI: 10.1016/j. scienta.2014.12.033.

DOORN, W.G. van; MEETEREN, U. van. Flower opening and closure: a review. Journal of Experimental Botany, v.54, p.1801-1812, 2003. DOI: 10.1093/jxb/erg213.

KIRBY, E.J.M. Factors affecting rate of leaf emergence in barley and wheat. Crop Science, v.35, p.11-19, 1995. DOI: 10.2135/ cropsci1995.0011183X003500010003x.

MARTINS, F.B.; PEREIRA, R.A. de A.; PINHEIRO, M.V.M.; ABREU, M.C. Desenvolvimento foliar em duas cultivares de oliveira estimado por duas categorias de modelos. Revista Brasileira de Meteorologia, v.29, p.505-514, 2014. DOI: 10.1590/0102-778620140020.

REICHARDT, K.; TIMM, L.C. Solo, planta e atmosfera: conceitos, processos e aplicações. 2.ed. Barueri: Manole, 2012. 524p.
REID, M.S.; EVANS, R.Y. Control of cut flower opening. Acta Horticulturae, v.181, p.45-54, 1986. DOI: 10.17660/ ActaHortic.1986.181.4.

RODRIGUES, R.C.; SOUSA, T.V.R.; MELO, M.A.A.; ARAÚJO, J.S.; LANA, R.P.; COSTA, C.S.; OLIVEIRA, M.E.; PARENTE, M.O.M.; SAMPAIO, I.B.M. Agronomic, morphogenic and structural characteristics of tropical forage grasses in northeast Brazil. Tropical Grasslands - ForrajesTropicales, v.2, p.214-222, 2014.

ROSA, H.T.; WALTER, L.C.; STRECK, N.A.; ALBERTO, C.A. Métodos de soma térmica e datas de semeadura na determinação de filocrono de cultivares de trigo. Pesquisa Agropecuária Brasileira, v.44, p.1374-1382, 2009. DOI: 10.1590/ S0100-204X2009001100002.

SCHWAB, N.T.; STRECK, N.A.; BECKER, C.C.; LANGNER, J.A.; UHLMANN, L.O.; RIBEIRO, B.S.M.R. A phenological scale for the development of Gladiolus. Annals of Applied Biology, v.166, p.496-507, 2015. DOI: 10.1111/aab.12198.

SCHWAB, N.T.; STRECK, N.A.; LANGNER, J.A.; RIBEIRO, B.S.M.R.; UHLMANN, L.O.; BECKER, C.C. Aplicabilidade do termo antocrono para representar a velocidade de abertura de flores em inflorescência. Pesquisa Agropecuária Brasileira, v.49, p.657-664, 2014. DOI: 10.1590/ S0100-204X2014000900001.

SKINNER, R.H.; NELSON, C.J. Estimation of potential tiller production and site usage during tall fescue canopy development. Annals of Botany, v.70, p.493-499, 1992.

STRECK, N.A.; WEISS, A.; XUE, Q.; BAENZIGER, P.S. Incorporating a chronology response into the prediction of leaf appearance rate in winter wheat. Annals of Botany, v.92, p.181-190, 2003. DOI: 10.1093/aob/mcg121.

STRECK, N.A.; BELLÉ, R.A.; BACKES, F.A.A.L.; GABRIEL, L.F.; UHLMANN, L.O.; BECKER, C.C. Desenvolvimento vegetativo e reprodutivo em gladíolo. Ciência Rural, v.42, p.1968-1974, 2012. DOI: 10.1590/ S0103-84782012001100010.

STRECK, N.A.; MICHELON, S.; ROSA, H.T.; WALTER, L.C.; BOSCO, L.C.; PAULA, G.M. de; CAMERA, C.; SAMBORANHA, F.K.; MARCOLIN, E.; LOPES, S.J. Filocrono de genótipos de arroz irrigado em função da época de semeadura. Ciência Rural, v.37, p.323-329, 2007. DOI: 10.1590/ S0103-84782007000200005.

TAIZ, L.; ZEIGER, E. Fisiologia vegetal. 4.ed. Porto Alegre: Artmed, 2009. 819p.

VIDAL, W.N.; VIDAL, M.R.R. Botânica - Organografia: quadros sinóticos ilustrados de fanerógamos. 4.ed. rev. e ampl. Viçosa: UFV, 2007. 149p.

WILHELM, W.W.; MCMASTER, G.S. Importance of the phyllochron in studying development and growth in grasses. Crop Science, v.35, p.1-3, 1995. DOI: 10.2135/ cropsci1995.0011183X003500010001x. 